\title{
Models of Public-Private Partnerships in Megaprojects: the Spanish case
}

\author{
Ana I. Irimia-Diéguez \\ Faculty of Economics and Business \\ Administration \\ of the University of Seville, Spain, \\ anairimia@us.es
}

Dolores Oliver-Alfonso

Faculty of Economics and Business

Administration

of the University of Seville, Spain,

moliver@us.es
DOI 10.5592/otmcj.2012.3.4

Research paper

\section{Keywords}

Public-Private Partnerships, Models of PPPs, Public sector, Megaproject, Spanish metro line
DUE TO BOTH BUDGETARY CONSTRAINTS ON THE PUBLIC SECTOR AND TO THE NEED TO OPTIMIZE FINANCIAL RESOURCES, SEVERAL MODELS AND METHODS OF PUBLIC-PRIVATE PARTNERSHIPS (PPPS) IN MEGAPROJECTS HAVE BEEN DEVELOPED IN THE CURRENT FINANCIAL CRISIS, ALTHOUGH THERE IS CONSIDERABLE CONFUSION AND AMBIGUITY AS TO HOW THESE MODELS SHOULD BE SYSTEMATIZED. This article provides a literature review of PPP Models, where the clarification of this current confusion and ambiguity constitute the fundamental issue addressed by our research. The systematization of the PPP models is performed by applying six classification criteria based on organizational and financial aspects and focused on the Spanish experience. Additionally, a comparative study of the various schemes applied in European countries is carried out, whereby the concession model implemented successfully in Spain is studied in greater detail. To this end, a megaproject, the first metro line of Seville (Spain) forms the basis of a case-study. When the megaproject is viable through user fees, the public sector can use PPPs to defer payments and as a way to control their deficits and debt without cutting investments in infrastructures and public services. Nevertheless, certain drawbacks should be borne in mind, such as the expenditure commitments of future budgets, the higher cost of private funding, and the necessity for transparency and accountability of PPP contractual arrangements to be improved. Therefore, the aim of this article is to analyze the various forms of PPPs in megaprojects in order to determine the potential efficiency gains that can be achieved in the implementation of these models. 


\section{INTRODUCTION}

The public-private participation in megaprojects has recently become the focus of great interest, despite the long tradition in EU countries of private sector involvement in public megaprojects. Due to both budgetary constraints on the public sector and to the need to optimize financial resources, especially in the current credit crunch, several models and methods of public-private partnership (PPP) have been developed.

PPPs models are an interesting alternative to be considered among others, which may be useful in attracting private capital to finance megaprojects, whilst introducing market criteria in their construction and operation. When PPP models are used, the public works are finally paid by the government (and, therefore by taxpayers). In general, all PPPs are more expensive than traditional debt operations (KPMG, 2009). Nevertheless, governments must continue investing in megaprojects (road infrastructures, underground transport, hospitals, etc.), and therefore, the first issue to be confirmed must be whether the megaproject is workable from a traditional budgetary point of view. If this first option is unfeasible, then alternative models should be analysed.

The current literature features a number of classifications of models of Public-Private Partnerships, although there is a considerable confusion around the notion of PPP and also ambiguity as to how the various models should be systematized (for example, see Saussier, 2012; Hodge et al., 2010; Ruuska and Teigland, 2009). Understanding and enhancing knowledge of PPPs continue to be a matter of significance and importance (Kwak et al., 2009). Practical problems in implementation appear due to the lack of knowledge and non-systematic approach in the research of PPPs (Milosavljevic and Benkovic, 2009). There is, therefore, a need for clear definitions and understanding of the concept of PPPs.
Due to the complex nature of PPPs, the literature covers a wide range of disciplines, including construction and project management, public policy and public administration, and project finance. Our research provides a literature review focused within the organizational and financial aspects of PPPs, where the clarification of this current confusion and ambiguity constitute the fundamental issue addressed by our research.

To the best of the authors' knowledge, no general comparison of models of PPPs is currently in existence. Therefore, our goals become the systematization and analysis of the different models of publicprivate partnerships by using organizational and financial criteria and focused on the Spanish experience. This research contributes towards the PPP literature by: (1) clarifying the PPP concept, (2) identifying the main features of PPPs, and (3) developing a conceptual framework for assessment of the efficiency of PPP projects.

The literature review offers various criteria for the classification of these partnerships, generally depending on the scheme of the division of responsibilities between the public and private functions of design, construction, financing, management, and payments of the megaproject. In our work, six classification criteria based on organizational and financial aspects and focused on the Spanish experience have been chosen:

1. The degree of responsibility assumed by the public sector in financing the megaproject.

2. The sources of financing and the levels of risk-taking in the public-private partnership.

3. The system of payments from the public to the private sector when the private sector is financing the megaproject.

4. The budgetary impact of private financing in public megaprojects.

5. The form of public intervention.

6. The degree of private sector involvement in the functions of design, construction, financing, management, and payments in the megaproject.
These criteria serve as a reference when designing strategies for publicprivate partnerships. The levels of sophistication within the PPP markets in each country are nonetheless at very different stages of development, thereby rendering international evaluations problematic. The public sector should absorb the lessons learned from the countries that pioneered PPPs and should combine this insight with proficient financial and legal expertise in order to create innovative and bespoke solutions for complex infrastructural megaprojects.

A comparative analysis between the various schemes applied in the European countries is then performed, whereby the concession model implemented successfully in Spain and exported to other countries is studied in greater detail (Vasallo and Izquierdo, 2007). The implementation of a new PPP model in the construction and exploitation of new metro lines in Spain is analyzed as a case study.

The rest of the paper is organized as follows. Section 2 presents the methodological approach and Section 3 the literature review. The definition and main characteristics of PPPs in the current context are analyzed in Section 4. Different classification criteria of PPP models are included in Section 5. A comparative analysis between the various schemes applied in the European countries is performed in Section 6 whilst an innovative Spanish model is presented in Section 7. Conclusions are drawn in Section 8.

\section{Methodological Approach}

To perform our research, we have conducted a thorough analysis of the scientific and professional literature. Our research is not just a descriptive list of the material available, nor is it simply a set of summaries. In this literature review, our purpose is to convey what knowledge and ideas have been established on the PPP topic, paying special attention to the organizational 
and financial aspects, and to inform stakeholders about their strengths and weaknesses thanks to the criteria analyzed which serve as a reference when designing strategies for PPPs.

A single case-study approach (Yin, 2003) has been then adopted to facilitate an understanding of the concept of PPP and to capture detailed qualitative and quantitative data. A megaproject, the first metro line of Seville (Spain), which forms the basis of this case-study, was inaugurated in $\mathbf{2 0 0 9}$, the Concession Agreement having been signed in June, 2003.

During this time, the following data-collection activities have been undertaken:

> Site visits and observations.

> Document and archive analysis was undertaken of minutes of meetings, status reports, and process flow diagrams.

> Interviews, which were conducted with project participants, the financial manager of the Society Metro de Sevilla, and stakeholders (literal transcriptions of the interviews can be found in Irimia and Oliver, 2010).

The analysis of the data was conducted inductively rather than taking a prior theory into consideration. This means that key themes such as dynamics of relationships, and organizational and financial issues emerged from the analysis of the data.

\section{Literature review}

Despite the fact that empirical studies have been flourishing recently in an effort to analyze particular aspects of PPPs (such as bidding processes, contractual choices, and renegotiations), PPPs have yet to be extensively studied from a theoretical point of view. According to Saussier (2012) a theory of public-private agreements is needed and still to be constructed; little has been done to focus on specific aspects of those arrangements, with respect to their differences with private-private agreements. Theoretical adjustments are probably necessary in order to provide for the specificities of public-private agreements and to enhance our understanding of their efficiency and/ or inefficiency in certain contexts.

Shaoul et al. (2012) stress the need for information to be accessible to the public, and in particular argue that a stream of information between the partners in the public and private sector needs to be developed and disseminated to achieve accountability for public money that is increasingly spent in the private sector. Benito and Montesinos (2009) analyze some proposals for the private financing of public works that have emerged in Spain in recent years and show that all the new financing methods assessed are incorrectly labelled as "private", since the payments are ultimately made by the Government by means of its budgetary resources. Allard and Trabant (2008) state that Spain presents an interesting paradox in the history of PPP. While it is one of Europe's oldest, most active and most enthusiastic users of PPPs, it is at the same time one of the countries that has demonstrated the least interest at an official level in informing, monitoring, regulating and following up projects to ensure that their principal benefits are being achieved.

An in-depth literature review on PPPrelated research over the last 20 years was performed by Kwak et al. (2009). The aim of the article is to facilitate a comprehensive understanding of PPPs through the discussion of the definitions, types, examples of worldwide applications, benefits, and obstacles of PPPs. Types of PPPs vary in terms of the degree of private involvement (our sixth criterion of classification) although only PPPs where the private sector also needs to contribute financially to the project, such as BOT (Build, Operate and Transfer) and PFI (Private Finance Initiative), lie within the focus of the article.

An interesting classification framework of PPP research is described by defining the following critical success factors and barriers for PPP projects:

1. Government Roles and Responsibilities, whereby the roles of the government in facilitating PPP projects are clarified.

2. Concessionaire Selection Methods and Criteria which are classified into four packages: financial; technical; safety, health, and environmental; and managerial.

3. Risk Identification and Allocation Strategies.

4. Financing Technique, Instruments, and Strategies.

Hodge and Greve (2007) state that there is still much confusion around notions of partnership, what can be learned about from our history with partnerships, and what is new about the partnership forms that are in vogue today. These authors argue that evaluations thus far point to contradictory results regarding their effectiveness and value-for-money. A typology of PPPs based on financial and organizational relationships is firs analyzed. One broad alternative view of PPPs is as a language game designed to "cloud" other strategies and purposes. They go on analyzing this option, with other authors, in latter publications such as Hodge et al. (2010), where the different interest of multiple stakeholders and the cross-disciplinarity of PPPs is also analyzed.

Conceptually, there are five different types of possible PPPs (Hodge et al, 2010):

1. Institutional cooperation for joint production and risk sharing (such as the Netherlands Port Authority).

2. Long-term infrastructure contracts (LTICS) that emphasize tight specification of outputs in long-term legal contracts, as exemplified in UK PFI projects.

3. Public policy networks, in which loose stakeholder relationships are emphasized.

4. Civil society and community de- 
velopment, in which partnership symbolism is adopted for cultural change.

5. Urban renewal and downtown economic development

Some alternatives to the PPP models can also be considered. According to Yescombe, (2007), these are the main alternatives that may be of worth consideration:

- Public-sector procurement, which may be adapted to achieve the main benefits of a PPP structure, without some of the drawbacks of cost and inflexibility. However, this will probably involve funding wholly provided by (or at the risk of) the public sector, with the budgetary disadvantages included.

> Post-construction take-out. As the highest-risk phase for a PPP is usually during construction, a post-construction take-out (or assumption of risk) by the Public Authority cuts out the 'higher' cost of private-sector funding thereafter in return for taking operation-phase risks. This also at least allows the Facility to be kept off the public-sector balance sheet during the construction phase.

\section{Public-sector debt funding.}

Using public-sector funding for the Project company's debt may be proposed as a way of reducing its capital-cost disadvantages, while leaving the rest of the standard PPP structure in place.

> Joint-Venture PPPs. In a Joint-Venture PPP the Public Authority becomes an equity shareholder, and, therefor the public sector shares in equity returns and any funding windfalls. This option will be developed in Section 6 .

> Not-for-profit structures. Another approach to reducing the cost of capital for PPP projects is to eliminate the equity return which goes to the private sector, or retain it for the benefit of the public sector. Paradoxically, however, this may result in higher initial service fees.
Steijn et al. (2011) study the assumption that a higher degree of PPP leads to more and better outcomes because public and private actors combine their knowledge and resources. They analyze whether the intensity and type of managerial strategies are more important than other factors for the outcomes. On one hand, they find partnerships that are characterized by either tight organizational forms or loosely coupled forms, and partnerships that are characterized by either a principle agent relationship between public and private actors or by a more equal relationship; the UK PFI is an example of a PPP with a principle agent relation and strong contractual ties. On the other hand, they also find joint consortia established by the partners together (tight form of principle-principle relation) and more network like partnerships (principleprinciple relations and more loosely coupled organizational form). Based on a large survey of individuals involved in Dutch environmental projects, Steijn et al. show that although the degree of PPP correlates positively with the outcomes of projects, this correlation disappears when the number of managerial strategies employed is included in the analysis. Therefore, greater attention should be paid to the managerial efforts necessary to develop and implement PPPs.

Not only do Ruuska and Teigland (2009) clearly demand more in-depth studies which compare types of PPPs, but they also indicate the need for research which focuses on the comparison of PPPs across other dimensions. Nevertheless, they only looked in-depth at one specific type of public-private partnership, a project in e-government in Sweden that involved 16 organizations from academia, government, and industry to develop an innovative internet portal for the private construction industry. Beck et al. (2009) conducted an exploratory, qualitative single-case study of the German Toll Collect case to analyze how this IT-PPP megaproject which had been on the verge of failure finally succeeded. They suggest that the deployment of boundary spanning activities and their specific antecedent conditions, moderated by external stakeholder support of a public-private environment, affects the formation of mutual trust and therefore the success of an IT megaproject in the context of PPPs.

Marrewijk et al. (2008) compare the project designs, daily practices, project cultures and management approaches of two megaprojects in the Netherlands and Australia, and show how these projects made sense of uncertainty, ambiguity and risk. The case studies suggest that managerial rationalities are limited in understanding their own complex project realities which are themselves bound by limits imposed by overall governance structures and strategies.

In addition to the clarification of the concept of PPP and the analysis of the main types of PPPs, another main issue studied is the evaluation of the performance of the different models. In this sense, Koontz and Thomas (2012) analyze how to measure the performance of these arrangements. Performance measures based on traditional governmental forms, such as centralized planning and regulation, are relatively straightforward. In collaborative governance, however, the wide range of policy tools for enabling and encouraging publicprivate partnerships (such as grants, contracts, and technical assistance), requires more nuance in distinguishing outputs from outcomes. These authors present a classification system for defining outputs and outcomes for various types of programs.

\section{Definition of Public-Private Partnership}

Contractually, megaprojects are often defined in terms of Public Private Partnerships (PPP), in which there is a structural cooperation between public and private parties to deliver some agreed outcome. PPP is a concept that involves working with public and private coop- 
eration and partnerships to deliver infrastructure and services to the population. It is an alternative structure that intermediates between state ownership on the one hand and, full privatization on the other.

The term PPP was coined in the United Kingdom in 1992, following the abolition in 1989 of the legislation that had previously restricted the use of private capital for the financing of public assets. Nevertheless, Spain was not a newcomer to PPP when megaprojects began to spread at the end of the 1990s; a simple form of PPP (a BOT model) was successfully performed in the 1970 s to construct numerous toll highways. It appeared natural for Spain to explore the PPP option under the conservative government in 1996, who focused on deregulating and privatizing the economy (Allard and Trabant, 2008).

The scheme was created due to a shortage of financial resources, and to the subsequent decrease in investment by the government. The public sector when accepting the participation of the private sector, establishes a partnership in order to manage an asset or business which provides a public service.

In a PPP, the public sector is responsible for the establishment of the investment priorities, scope and standards required for public services and the identification of community needs. The private sector must find the most cost-effective combination required by such services and/or public infrastructure, in terms of the design, construction, operation and maintenance, work practices and financial capital.

The main justification for PPPs is the possibility to exploit the management expertise and the efficiency of the private sector without giving up quality standards, thanks to appropriate control mechanisms from the public sector. Although a PPP leads major advantages, it may involve an additional financial cost and, in the absence of adequate controls, it can also damage the quality of public services.
It might be expected that the demand for PPPs from governments would increase in response to the recession, since these partnerships represent a way of building infrastructure whilst limiting the effect on the official government deficit. In this crisis context, one of the main reasons for the creation of a PPP is to prevent any such impact of megaprojects on the government deficit, or, at least, to defer or minimize such impact.

The recession also provides private companies with even greater incentives to sign PPP contracts: they receive longterm business from the government at a time when demand from the private sector is falling. However, the credit crisis means that banks and investors are much more reluctant to lend to private companies at all. Several authors such as Hall (2009) state that as a result, companies are largely unable to borrow money to finance PPPs.

From a budgetary perspective, one major issue concerns the way in which megaproject concessions have an impact on the budget deficit. Obviously, the annual payment of the fee is considered an expense and is computed annually in the budget. With respect to investments linked to a megaproject, Eurostat recommends that the following conditions must be observed so that the deficit remains out of the scope of the government's responsibility: (a) the private sector bears the risks of construction and, (b) the private sector also bears the risks involved in availability and/or risks in demand. Benito and Montesinos (2009) conclude that many countries have used PPPs to defer payment and this way control their deficits and debt without cutting investments in infrastructures and public services, but payments are finally made by the Governments.

Searching for new models of PPPs requires lots of imagination. On the one hand, a high quality in public services must be obtained, and on the other hand, a rigid budgetary discipline has to be achieved.

\section{Types of models of public- private partnerships in Megaprojects}

The current literature features a number of classifications of PPPs, although there is a considerable confusion and ambiguity as to how the various models should be systematized, as mentioned previously.

In our work, the criteria for the classification of these partnerships have been selected depending on the scheme of division of responsibilities between the public and private functions for financing, management, and payments of the megaproject and based in the Spanish experience. These six classification criteria are shown in Figure 1.

The classification criteria are:

1. The degree of responsibility assumed by the public sector in financing the megaproject. The involvement of the public sector in financing the megaproject, according to the responsibility assumed by the relevant Administration and the degree of private sector participation, can take place through any of seven different models (Sardá, 2005):

> Public Model: all functions are assumed by the public sector, for example in the case of the free use of roads.

- Public Model with Private Payment: all functions are assumed by the public sector, except the payment, for example in the case of the Spanish railway system.

- Public Model with Private Management: the private sector is responsible for the management, while other functions are performed by the relevant government administration. This model is designed to take advantage of potential efficiency improvements that can arise from management by the private sector. This model has been applied in some hospitals in Spain.

- Private Model: a private enterprise assumes all the responsibilities. It is difficult to find a pure private model, but 
Degree of responsibility assumed by the public sector in financing the megaproject

Public Model

> Public Model with Private Payment

- Public Model with Private Management

- Private Model

- Private Model with Public Payment

- Privatized Public Model

- Private Socialized Model
Sources of financing and levels of risk-taking

Public sector seeks private funding, but assumes the risk of the megaproject

- Private sector provides financing and shares risk

- Private sector fully assumes the risks but follows the guidelines dictated by the public sector

Form in which the public sector interevene in the different phases of the megaproject sources of financing and levels of risk-taking

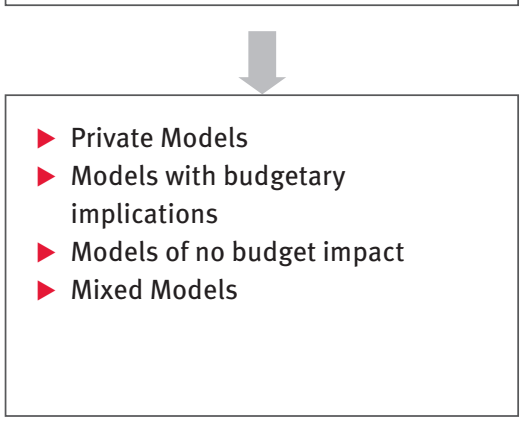

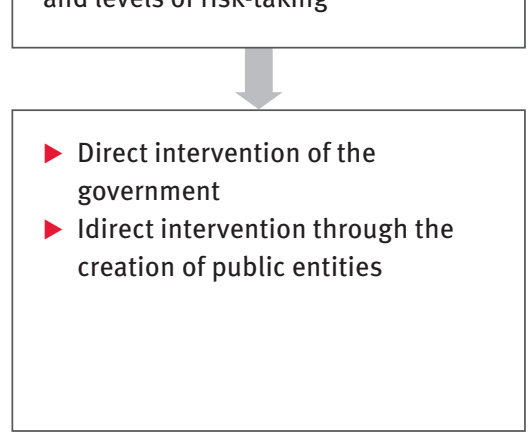

Figure 1 Types of models of public-private partnership in Megaprojects

a good approximation can be found in toll road concessions.

Private Model with Public Payment: all the responsibilities are for a private enterprise, except the payment, which will be provided by the public sector. A clear example of the application of this model is found in motorway concessions with the system of "shadow tolls", which are later discussed in greater detail.

- Privatized Public Model: this corresponds to services that the state has built and funded, but remains managed by the private sector, and payment is provided by the user. $\mathrm{Nu}$ merous examples can be observed in privatizations carried out in Argentina.

- Private Socialized Model: this applies to infrastructure constructed and financed by the private sector, which is rented to the public sector for man- agement and payment. This model has been applied in power plants.

2. By taking into account the source of funding and the assumption of risks, we can identify possible types of private collaboration with public megaprojects (Irimia and Oliver, 2010):

> The public sector seeks private funding for its projects, but assumes the risk of providing the service. The private sector is just a source of external finance. In this case, there is no incentive for the private sector to improve the allocation of public investment since it assumes no risk, and therefore requires no conditions.

The private sector provides financing and shares risk.

- The private sector fully assumes the risks but follows the guidelines dictated by the public sector. In these
The system of payments from public to private sector

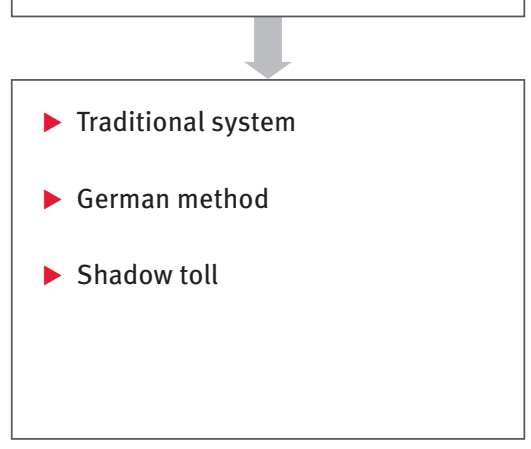

Degree of involvement by the private sector in the various functions
- BO Model
- BOT Model
- BTO Model
- BBO Model
- DFBO Model
- LDO Model
- WAA Model

cases there may be problems in obtaining all the necessary financing and/or guarantees, given the scale of these projects, hence the scarcity of projects that follow this type of collaboration.

3. The system of payments from public to private sector generates the following formulas:

Traditional system. The traditional system consists of paying the builder with payments on account (labour certification) as a closed budget and approved by the Administration, subject to price revisions when derived.

- The German method. Also known as total price payment or key on hand method. In this case, the Administration signs a contract with the successful private company tendered for building and financing the project, whereby the building costs 
and interests are reimbursed after the full completion of the work. No partial payment account is therefore required. The contractor is obliged, consequently, to finance the construction, advancing the quantities needed until there is receipt of the completed work. This formula has been widely used in Germany (hence the name) for highway construction (Vasallo and Izquierdo, 2007). Once the public megaproject is up and running, then the Administration may choose to pay either the full agreed price in a lump sum or in up to ten annual instalments; thereby allowing the possibility for the contractor to convert these future payments into tolls to be paid by the megaproject users. The main reason given for the use of this funding model is that it defers the entry of this investment into the government accounts to a date after the execution of the work, whilst simultaneously, deferring any public debt arising from the operation. This German method has been used by the Spanish Central Administration (Irimia and Oliver, 2010). According to Benito and Montesinos (2009), the current EU accounting standard (ESA 95) establish that investment expenses must be reported along the years of construction (accrual accounting), whilst the previous approach under ESA 70 reported the expenses according to the payments made (cash accounting). The result of taking into account these accounting rules is the suspension of the use of this financing method according to additional dispositions of the laws passing the State General Budgets in Spain.

The shadow toll; the infrastructure is built and operated by the concessionaire. The public administration just pays to the private agent the corresponding rates in order to get services provided by using the assets constructed. The payment is made by means of periodic amounts of money which depends upon the use of the infrastructure by the citizens (Benito and Montesinos, 2003). The concessionaire does not assume the risk that the infrastructure is underutilized, since the Administration will ensure a level of income with which to achieve financial balance. According to Vasallo and Izquierdo (2007), the difference of this kind of contracts and pure concessions is that is the government who pays the rates, not the users. It is easy to see that the economic and financial background model based on the "shadow toll" is practically the same as what is known as "operating lease". Sometimes, the megaproject's ownership is transferred to the public sector at the end of the operating period, and then it is closer to a finance lease. This model implies, as conceived in countries like France and Germany, the approval by the Public Administration of the temporary occupation of a public domain by the leasing company that both builds and finances the work. This model is currently in use in various countries. Thus, in Britain, the Roads Act of 1991 articulated a new system of toll road construction by the private sector, through a contractual relationship with the state, which reflects the principle that each project should be financed with user tolls without warranty or support from the state, whereby the developer or contractor runs all the risks in the construction and operation. Since road users in Britain are not accustomed to paying tolls, the public sector is expected to pay the road runs for the first years (hence the famous name of shadow toll). However, it is anticipated that the British state can also assist in the financing of these infrastructures through operating subsidies, earmarked taxes, exchange guarantees, refunding advances, subsidized credits, tax exemptions, etc. The shadow toll method has been used in Spain as a licence system where private sector is engaged to build and maintain the infrastructure, and the public sector pays a toll for its use, until the settlement of financial commitments. When the concession term is over, the megaproject becomes a public ownership, without additional cost for the public sector.

4. According to the budgetary impact of the private financing of the public megaproject, the following models are allocated (Irimia and Oliver, 2010):

> Private Models. If a project is to be funded entirely by the private sector and there is no financial link with the public sector, then generally the only role of government is to grant permission for the construction and operation and to exercise supervisory and control functions. Once the project is approved, the private provider can obtain the necessary funds, which can probably be achieved in one or more of the following ways: capital, credit, and/or bonds. The financial structure of the megaproject is likely to be affected by the conditions of the concession and the guarantees attached to the funds. As regards the conditions of the concession, in some cases the only security available to the provider of funding is the stream of revenue from the operation of the facility, although public commitments are sometimes incurred. The first phase of the megaproject usually requires a high proportion of financing through capital, thereby starting the project with a low leverage ratio unless the debt may be guaranteed by parent companies or other guarantors, usually in the form of the issue of bonds during the construction phase. Once the infrastructure is in place, these bonds can be used to refinance existing loans. Due to these circumstances, the cases of totally private financing are rare. There is often some type of public sector involvement, either through capital injections, debt underwriting, and guaranteeing the debt, or through guaranteeing a certain level of income stream. 
Models with budgetary implications. It is first necessary to clarify that private financing of public infrastructure does not necessarily mean privatization. However, if the State agrees to reimburse the amount of financing in full, then this has an impact on the public budget and the problems of public deficits may persist. In these cases, the state continues to bear all the risk and, therefore, private funding does not implement stricter criteria for viability.

- Models of no budget impact. In this type, those partnerships in which there is a mix between public administration and private payment are included. In other words, the cost of the megaproject is supported by the users and not by taxpayers in general. Two examples in Spain are the Public Corporations (Airport Company, AENA, and the Port Authority) and the State Highway Societies. In the former, investments are funded through fees paid by users, while the latter is paid for through the collection of tolls set by the private company.

> Mixed Models. This group may include all those formulas in which the executor of the infrastructure is paid by a combination of public and private resources. For example, in the case of the Spanish State Water Corporation, there is a combination of public and private resources that are articulated in the agreements signed with these companies and individuals for the realization of hydraulic works.

5. The form in which the public sector intervenes in the different phases of the megaprojects, leads us to distinguish between:

D Direct intervention of the government.

- Indirect intervention through the creation of public companies and public entities.

It is worth going into greater depth in the latter model: the creation of public companies and public entities. As stated in Gutierrez de Vera (2004), it is necessary to differentiate between the effect of investments made by public companies that develop a real business, with income generation, such as RENFE or AENA, whose spending on investment is not consolidated with public spending, from those purely instrumental companies, which obtained the necessary funds (in the form of debt) by accessing certain commitments by the Public Entity creator and main shareholder. Regardless of the operative efficiency of the new public entity, the debt included in its balance sheet which will be paid off by the public sector, will be computed as public deficit. Furthermore, the investment will be entered as an expense, thereby increasing the public debt in the year it is performed. Nevertheless, certain combinations of these public entities, as it will be explained later, can be used in order to avoid the consolidation of the debt in the public budget.

6. The degree of the private sector involvement in terms of design, construction, financing, management and payment infrastructure is determined both by a single model called concession, and by several variants which can take place. The concession model has traditionally been the PPP formula most commonly used in Spain. Notwithstanding, it should be borne in mind, as mentioned above, that it is not a single model, since under the concession formula a variety of types with different characteristics can be implemented. The existing arrangements are:

BO Model (Build and Operate): it is a model granted in perpetuity, where a private entity finances, builds and manages without any time limit, where the Administration assumes the task of control.

BOT Model (Build, Operate and Transfer): in this case, the concession has a limited time within which the private sector builds and manages. During the period of the infrastructure management by the private enterprise, the investment is recovered and the expected return is obtained. At the end of the concession, the ownership of the project becomes public.

- BTO Model (Build, Transfer and Operate): the project ownership becomes public before its operation. When the construction phase is completed, the private sector leases the project to the public sector. This system is recommended when the responsibilities and risks of the project lie beyond the building stage.

BBO Model (Buy, Build and Operate): this system involves a private company which purchases certain public infrastructure for its management, after the completion of repairs and/or extension thereof. This formula is suitable for the development of infrastructures that are damaged or congested.

D DFBO Model (Design, Finance, Build and Operate), under which the concessionaire, usually privately, designs, builds, finances and manages the infrastructure. The Administration pays for the provision of services arising from public works built by the shadow toll system, as discussed above. Such contracts are, in short, almost identical to pure concession models, with the only difference being that it is the Administration who pays and not the users, and hence, this method of financing may be treated as an operating lease. In some cases, it is possible that the infrastructure reverts to the Administration at the end of the operation period, in which case it more closely resembles a finance lease.

- LDO Model (Lease, Develop and Operate): in this case, a company leases certain assets to the government, and manages the repair during the term of the concession.

- WAA Model (Wraparound Addition): where the private entity extends publicly owned and operated infrastructure. Such management may corre- 


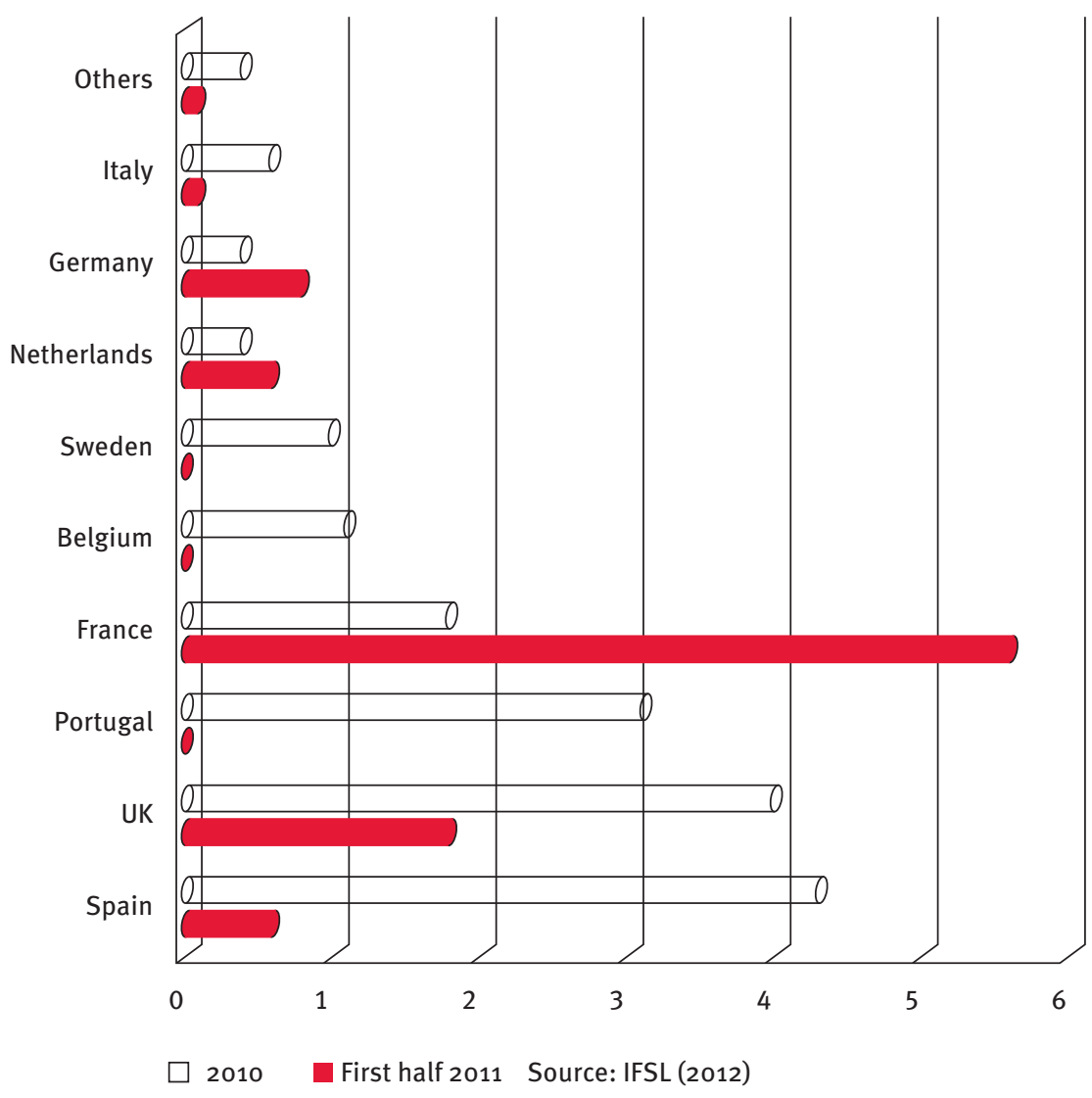

Figure 2 PPP contracts reaching financial close in Europe by country

spond to the entire infrastructure or only to the extended part. When the operation is complete, the ownership is shared, since the extension belongs only to the private enterprise.

\section{A comparative analysis between the various schemes applied in the European countries}

The PPP formula first emerged in the United Kingdom in the wake of the conservative revolution of Margaret Thatcher. Beginning in the early 1990 , the PFI (Private Financing Initiative), as it was called in the UK, spread quickly across sectors and took various forms, depending on the exact role that each project assigned to the private and public sectors. Through its PFI, the UK government makes use of partnership models to develop and deliver all manner of infrastructure, from schools to defense facilities. PFI projects now represent between 10 and 13 percent of all
UK investment in public infrastructure (Deloitte, 2006). The United Kingdom has pioneered the trend; their use has spread from the United Kingdom to Europe. The European Commission (see for example, Commission of the European Communities, 2009) has over many years promoted Public-Private participation schemes.

Spain had experience in PPP when projects involving cooperation between the public and private sectors began to spread in size and variety at the end of the 1990s. The concession model used successfully in Spain and Latin America and even exported to the United States, is proof of its success. Public participation schemes mixed with private funding formulas can also be found in Spain, in which the government provides financial support for socially beneficial projects that fail to achieve the financial breakeven point.

According to IFSL (2012), 44 PPP deals in the UK in 2010 was the highest number in the EU, although UK PPP deal value of $€ 3.9 b n$ was less than Spain where deals reaching financial close totalled $€ 4$.3 bn. Other significant PPP markets included

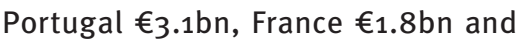
Belgium $€$ 1.7bn (Figure 2). Since 1990, around 1,500 PPP deals in Europe have reached financial close with a capital value of $€ 282 \mathrm{bn}$. The UK has accounted for about half of European PPP activity by value.

The importance of Spain as one of the most important PPP markets in the world is also attested by the presence of all Spanish specialized banks and promoters in these processes. The Spanish Transport Infrastructure Plan (Programa Extraordinario de Infraestrucutras de Transporte, PEIT) will invest $€ 17,000$ million until the year 2020 in new and improved highways, railways, airports, ports and other infraestructures. The government plans to obtain $40 \%$ of total financing from the private sector, 20-30\% from public banks (Instituto de Crédito Oficial, ICO) and the remaining from the European Investment Bank (Díaz, 2011).

The comparison of PPP experiences leads to identify three types of PPP models: Spanish, Anglo and Auction. These schemes differ in the bidding models, as shown in Table 1.

The complex nature of the PPP tendering process implies high bid costs relative to conventional procurement models, which act as an entry barrier by discouraging contractor participation in PPP projects. The UK has one of the most elongated and expensive tendering processes for PPP projects. The duration of the tendering process varies across government departments but is on average about 34 months (Adair et al., 2011). By contrast the tendering process in Spain is much more streamlined taking on average between 4-6 months. The basics of the Spanish model are: > Short bidding processes (6 months), with requirements of high standards of technical and economic soundness (but simple documentation). 
Negotiation of concession framework
Reduced
Intense
Medium

\begin{tabular}{|c|c|c|c|}
\hline Securing funding & Not required & Indispensable & Indispensable \\
\hline Cost of bidding & $\begin{array}{c}\text { Medium } \\
0.6 \text { to } 1 \text { M. } €\end{array}$ & $\begin{array}{c}\text { High } \\
1.5 \text { to } 2 \text { M. } €\end{array}$ & $\begin{array}{c}\text { High } \\
1.2 \text { to } 1.8 \text { M.€ }\end{array}$ \\
\hline Duration of process & $\begin{array}{c}\text { Reduced } \\
<4 \text { months + decision }\end{array}$ & $\begin{array}{l}\text { Very high } \\
2 \text { years }\end{array}$ & $\begin{array}{l}\text { Reduced } \\
6 \text { months }\end{array}$ \\
\hline Degree of objectivity & $\begin{array}{c}\text { Medium } \\
30 \text { to } 50 \% \text { subjective }\end{array}$ & $\begin{array}{c}\text { Medium-High } \\
15 \text { to } 30 \% \text { subjective }\end{array}$ & $\begin{array}{c}\text { High } \\
100 \% \text { objective }\end{array}$ \\
\hline Geographical Location & Spain, France and Italy & $\begin{array}{l}\text { UK, Ireland, Portugal, } \\
\text { Holland, Greece, Germany }\end{array}$ & Canada, USA \\
\hline
\end{tabular}

Table 1 Bidding models in PPP schemes Source: Irmia and Oliver (2010).

Relatively straightforward contracts relying upon the specific legal framework (Law on Concessions of Public Works).

> Simple and reasonably standardized contractual framework, without the rigidity required to impose a standard.

- A balanced sharing of the risk, clearly defined in the contract.

- High importance given to the quality of the initial project, not only to the levels of compliance in the operation.

- A relatively high importance is granted to the solvency and viability of the offer, not just to the bidder.

The only innovation in the Spanish Law was to import the Anglo concept of "Value for Money" (hereinafter, VfM). This law specifies, in its Article 118, the requirement of a comparative analysis that justifies the use of this formula in terms of obtaining greater value for price. VfM is defined, by HM Treasury (2006), as the optimum combination of wholeof-life costs and quality (or fitness for purpose) of the good or service to meet the user's requirement. Therefore, VfM is not the choice of goods and services based on the lowest cost bid; VfM is a relative concept which requires comparison of the potential or actual outcomes of alternative procurement options.
VfM essentially comprises three strands; efficiency, risk transfer and whole life costs. In order to meet this criteria, the most suitable model for the execution of the megaproject must be chosen, ex-ante and from among various alternatives. To this end, all the constraints, whatever their nature, are taken into account in order to determine which alternative offers the lowest possible overall cost to the community in general and, in particular to the Administration responsible. This comparative quantitative analysis requires, for each alternative, the estimation and disaggregation of costs and revenues that may be generated over the lifetime of the project (HM Treasury, 2011).

Concerns persist about the credibility of the VfM argument used to support PPP projects (Adair et al., 2011). There is an information vacuum preventing robust quantitative and objective evaluation. The absence of credible datasets must be addressed in order to improve the transparency and accountability of PPP contractual arrangements. Flyvbjerg et al. (2003) contend that the majority of megaprojects overrun on costs, fall behind schedule, and fail to deliver in the terms used to justify the need for the project. They suggest that a main cause of such overruns is a lack of realism in initial cost estimates.
Experience in the UK and other countries has demonstrated that PPP is not appropriate for all projects (Allard and Trabant, 2008). Choosing PPP without carefully contrasting the public and private costs for each project may turn out to be a more costly option for taxpayers and the final users of the services provided by a PPP.

Added to this risk is the danger that PPP projects that are not carefully monitored may not meet the expected standards of quality, or may experience cost overruns that are charged back to the public sector or to the final user. One of the main risks in awarding a contract to an underpricing bidder is that if the offer is too low and the company cannot cover costs, it will pressure the government to renegotiate the contract at a higher price.

\section{A Review of the Spanish Experience of Megaproject PPP}

More transparency and effective communication among the different levels of the public sector in Spain is required. The Spanish public sector is organized in three levels: State or Central Administration, Autonomous Communities or Regions (17), and Local Entities The Spanish government has yet to make model contracts available to its various ministries and levels of government, and no 


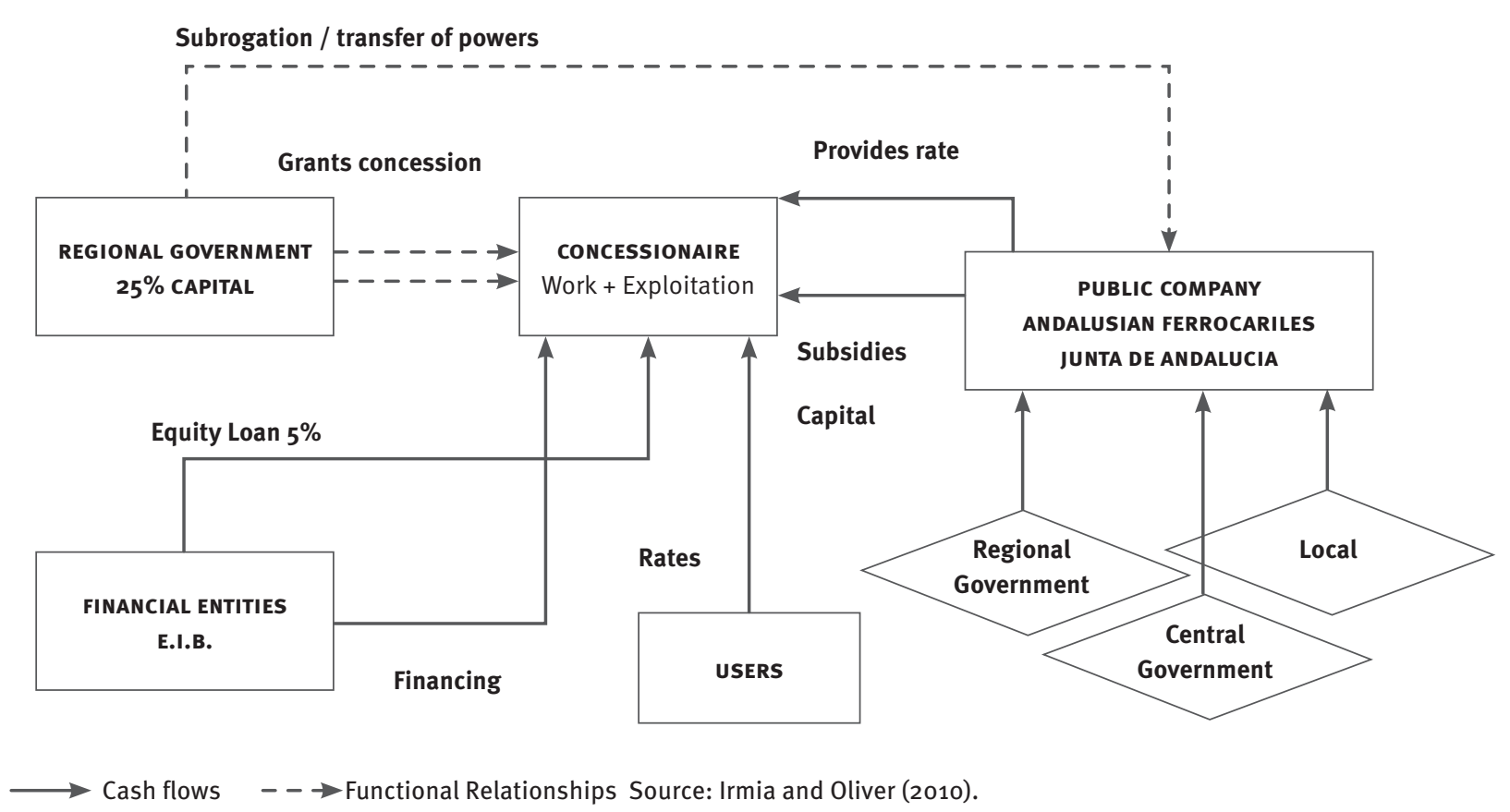

Figure 3 Relationships among stakeholders in the Concession for Andalusian Metro Lines

public-sector comparator has yet been developed or adapted that could be used to determine whether using the PPP formula for a project offers potential Value for Money. The Spanish government does not maintain an official register and details of biddings are not always publicly available. Duplicated projects should be avoided and the public requires more information on the reasons for employing a PPP and its potential benefits.

One innovative model has been applied to two Andalusian megaprojects, the Seville and Malaga metro lines. These megaprojects have involved public and private sectors as shareholders in a concessionaire company. It is unusual to see the Central Government sharing risks and management with the private sector in a company; nevertheless, the participation of the public sector at different levels (local, regional and central) is even less frequent.

In the case of Seville, the Concessionaire is a Limited Company with an initial equity equivalent to $20 \%$ of total investment. The final investment in infrastructure and facilities of the Metro
Line 1 amounted to $658,020,037$ euros. The public sector had an initial shareholding of $25 \%$, and equity loans up to $5 \%$ of the investment could be granted. Several private companies such as Itinere, Iridium, CAF were also shareholders of the Concessionaire. The European Investment Bank (E.I.B.) financed up to $25 \%$, and the remaining amount was granted as subsidies from a public company. After three years of construction (and a certain delay), the exploitation of the megaproject is finally underway. Due to the success of the megaproject, the private companies have bought part of the shares from the public sector. Figure 3 shows the main relationships among the stakeholders.

According to the six previous criteria described in Section 5 , this innovative model can be classified in the following way:

- It is a Private Model since a private enterprise assumes all the responsibilities. The innovation is that the public sector is a minority shareholder of this company.

- The private sector fully assumes the risks, although it follows the guide- lines dictated by the public sector. By taking into account the source of funding, there is a mix of public and private financing. Due to the high level of leverage of the megaproject, various private companies participate in the financing of the investment and the presence of the public sector is necessary.

By considering the system of payments, this model is similar to a shadow toll where the concessionaire assumes the risk of demand. The risk of demand consists of the assumption of a certain level of use. Therefore, the remuneration of the concessionaire is based on its initial financial offer and the real traffic of users.

It is a Model of no budget impact due to the transfer of the risks of demand and constructions to the private sector. The relevance of this fact is that the investment is recorded on the balance sheet of the private sector. Therefore, this megaproject does not increase the public deficit (except obviously for the amount of investment subsidized during construction). For the same reason, the debt 
produced from financing the investment is not counted as public debt. The payments made by the public sector, over the life of the concession as compensation for the service, are linked to the price subsidy. Therefore, the short-term effect is to reduce the total government expenditure and the budget deficit. In the long term, the future stream of fees and payments to the private partner must also be taken into consideration.

- There is Indirect intervention by the public sector; a new public company called GIASA (Gestión de Infraestructuras de Andalucía, S.A.) designed the bidding process and was one of the shareholders of the concessionaire company.

- The BOT Model was built by the private sector; is now being operated by the private sector, and will return to the public sector at the end of the concession period 35 years.

\section{Concluding remarks}

The classification criteria of PPPs shown in the second section enable stakeholders to ascertain the most suitable model according to their priorities. Which model is best? Each model fits into a certain type of megaproject in that it obtains the highest Value for Money in providing a public service and strives to minimize or eliminate the cost to the public sector. The public sector can use PPPs to defer payments and as a way to control their deficits and debt without cutting investments in infrastructures and public services, although payments are ultimately made by the Governments by means of its budgetary resources. When the megaproject is not viable through user fees, the contract is usually awarded to the company that best minimizes the present value of government payments for the life of the contract.

Among the advantages of PPP models, several deserve a special mention: (a) the advancement of the use of the new infrastructure; (b) the implementation of deadlines; (c) the control of costs; and (d) the greater efficiency attributed to the private sector.

Nevertheless, certain drawbacks should be borne in mind: (a) the expenditure commitments of future budgets, which will limit the financing of new projects within a framework of budgetary stability; (b) the higher cost of private funding compared to traditional financing through public debt; and (c) the necessity for transparency and accountability of PPP contractual arrangements to be improved.

Thanks to the sophistication in the Spanish model, only surpassed by that of the UK, countries positioned lower on the maturity curve can benefit from a deeper understanding of the challenges and potential solutions particular to each area of infrastructure.

In our opinion, the keys to success of the Spanish model include:

- The long tradition. There are records of privately constructed highways in Spain in the 19th century, and former dictator Francisco Franco successfully used a simple form of BOT in the 1970 s to construct numerous toll highways.

- An ad-hoc legal framework. The Spanish Law 30/2007, dated October 30, of Contracts of the Public Sector regulates the wide incorporation of PPPs into Spanish legislation.

- A more efficient process due to the short duration of the contract, to their lower costs and, to increased competition.

The high level of contrast in the tendering process is due to the high competition among the private companies that present their offer.

\section{References}

Adair, A., Berry, J., Gulati, M., Haran, M. and Hutchison, N. (2011), “The future of private finance initiative and public private partnership", available at http:// questantinc.com/images/Articles $\% 20$ and $\% 20$ News \%20Media/Newsworthy/ RICS_PPP\%2odraftreportfordistribution. pdf (accessed 28 June 2012).

Allard, G. and Trabant, A. (2008), "PublicPrivate Partnerships In Spain: Lessons And Opportunities”. International Business \& Economics Research Journal. February Volume 7, Number 2, pp 1-24.

Beck, R., Marschollek, O., and Gregory, R. (2009), "The Role of Boundary Spanning in Public-Private IT Megaprojects”, International Research Workshop on IT Project Management 2009. Paper 1, available at http://aisel.aisnet.org/ irwitpm2009/1 (accessed 18 June 2012).

Benito, B., Montesinos, V. (2003), “Análisis de la financiación ¿privada? de infraestructuras”, Revista Valenciana de Economía y Hacienda, no 9-III, pp. 9-28.

Benito, B., Montesinos, V. (2009), “An example of creative accounting in public sector: The private financing of infrastructures in Spain", Critical Perspectives on Accounting, 19, pp. 963-986.

Commission of the European Communities (2009), "Mobilising private and public investment for recovery and long term structural change: developing Public Private Partnerships", COM(2009) 615 final Brussels, 19.11.2009, available at http://ec.europa.eu/growthandjobs/pdf/ european-economic-recovery-plan/ppp_ en.pdf (accessed 11 June 2012).

Deloitte (2006), “Closing the infrastructure gap: The Role of Public-Private Partnerships", A Deloitte Research Study, available at http://www.deloitte.com/view/ en_IE/ie/industries/publicsector/8dae3f9 5C3efd110VgnVCM10000oba42fooaRCRD. htm (accessed 20 June 2012).

Díaz Pérez, J. (2011), “Retos de la colaboración público-privada para el desarrollo de infraestructuras públicas", Boletín Económico del ICE, No. 3012, Junio, pp. 15-31.

Flyvbjerg, B., Bruzelius, N., Rothengatter, W. (2003), Megaprojects and Risk. An Anatomy of Ambition, Cambridge University Press, Cambridge. 
Gutierrez de Vera, F. (2004), “Mecanismos de financiación de infraestructuras”, Revista de Obras Públicas, enero, No. 3440.

Hall, D. (2009), “A crisis for public-private partnerships (PPPs)?”, available at http:// www.psiru.org/reports/2009-01-crisis-2. doc (accessed 20 June 2012).

Hall, D. (2010), “More public rescues for more private finance failures - a critique of the EC Communication on PPPs", available at http://www.psiru.org/reports/2010-03PPPs.doc (accessed 2 June 2012).

HM Treasury (2006), "Value for Money. Assessment Guidance”, Available at http://www.hm-treasury.gov.uk/d/ vfm_assessmentguidanceo61006opt.pdf (accessed 2 May 2012).

HM Treasury (2011), “Quantitative assessment. User guide”, available at http://www.hmtreasury.gov.uk/d/vfm_qa_guide_122011. pdf (accessed 2 May 2012).

Hodge, G. A. and Greve, C. (2007), "Publicprivate partnerships: an international performance review", Public Administration Review 67(3), pp. 545-558.

Hodge, G. A., Greve, C. and Boardman, A.E. (2010), International Handbook on PublicPrivate Partnerships, Ed. Cheltenham: Edward Elgar Pub.

IFSL (2012), “PFI in the UK \& PPP in Europe 2012", available at http://www. thecityuk.com/home/ZendSearchLu ceneForm?Section $=\&$ Search $=\mathrm{PFI}+$ in +the+UK+\%26+PPP+in+Europe\&acti on_ZendSearchLuceneResults $=$ Search (accessed 5 October 2012).

Irimia Diéguez, A. and Oliver Alfonso, M.D. (2010), Financiación Privada de Infraestructuras. Ed. Escuela Andaluza de Economía.

Koontz, T. M. and Thomas, C. W. (2012), "Measuring the Performance of PublicPrivate Partnerships”, Public Performance \& Management Review 35(4), pp. 769-786.

KPMG (2009), "Primeras impresiones: CINIIF 12: Acuerdos de Concesión de Servicios. Normas Internacionales de Información Financiera", available at http://www. kpmg.com/ES/es/ActualidadyNovedades/ ArticulosyPublicaciones/Documents/ Primeras_Impresiones_CINIIF_12.pdf (accessed 7 May 2012).
Kwak, Y. H., Chih, Y., Ibbs, C.W. (2009), "Towards a comprehensive understanding of public private partnerships for infrastructure development", California Management Review, 51(2), pp. 51-78.

Marrewijk, A., Clegg, S.R., Pitsis, T.S. and Veenswijk, M. (2008), “Managing PublicPrivate Megaprojects: Paradoxes, Complexity and Project Design”, International Journal of Project Management.

Milosavljevic, M. and Benkovic, S. (2009), “Modern Aspects of Public-Private Partnership”, Perspectives of Innovations, Economics \& Business, Volume 3, pp. 25-28.

Ruuska, I. and Teigland, R. (2009), “Ensuring project success through collective competence and creative conflict in publicprivate partnerships-A case study of Bygga Villa, a Swedish triple helix e-government initiative", International Journal of Project Management, 27(4), pp. 323-334.

Sardá García, S. (2005), La titulización de derechos de crédito futuros: propuesta de una metodología aplicada a los peajes de autopista. Tesis doctoral, Universidad Rovira i Vigili. Available at http://hdl.handle. net/10803/8808 (accessed 5 May 2008).

Saussier, S. (2012), “Public-private partnerships”, J. Econ. Behav. Organ, available at http://dx.doi.org/10.1016/j. jebo.2012.05.001 (accessed 5 October 2012).

Shaoul, J., Stafford, A., Stapleton, P. (2012), "Accountability and corporate governance of public private partnerships", Critical Perspectives on Accounting, 23, pp. 213-229.

Steijn, B., Klijn, E. H. (2011), “Public Private Partnerships: Added Value by Organizational Form or Management?", Public Administration, 89(4), pp. 1235-1252.

Vasallo, J.M. and Izquierdo, R. (2007): “La participación público privada en el nuevo proyecto de Ley de Contratos del Sector Público", Revista de Obras Públicas, junio, No. 3478 .

Yescombe, E. R. (2007), Public-Private Partnerships: Principles of Policy and Finance, Elsevier Finance, Great Britain.

Yin, R.K. (2003), Case Study Research Design and Methods, zrd ed., Sage Publications, Thousand Oaks, CA./ 